\title{
Reduced prostate branching morphogenesis in stromal fibroblast, but not in epithelial, estrogen receptor $\alpha$ knockout mice
}

\begin{abstract}
Ming Chen ${ }^{1, *}$, Chiuan-Ren Yeh ${ }^{1, *}$, Chih-Rong Shyr ${ }^{2}$, Hsiu-Hsia Lin ${ }^{1}, J^{\prime} \operatorname{Da}^{1}$ and Shuyuan Yeh ${ }^{1}$
Early studies suggested that estrogen receptor alpha (ER $\alpha)$ is involved in estrogen-mediated imprinting effects in prostate development. We recently reported a more complete ER $\alpha$ knockout (KO) mouse model via mating $\beta$-actin Cre transgenic mice with floxed ER $\alpha$ mice. These ACTB-ERaKO male mice showed defects in prostatic branching morphogenesis, which demonstrates that ER $\alpha$ is necessary to maintain proliferative events in the prostate. However, within which prostate cell type ER $\alpha$ exerts those important functions remains to be elucidated. To address this, we have bred floxed ER $\alpha$ mice with either fibroblast-specific protein (FSP)-Cre or probasin-Cre transgenic mice to generate a mouse model that has deleted ER $\alpha$ gene in either stromal fibroblast (FSP-ERaKO) or epithelial (pes-ERaKO) prostate cells. We found that circulating testosterone and fertility were not altered in FSP-ERaKO and pes-ERaKO male mice. Prostates of FSP-ERaKO mice have less branching morphogenesis compared to that of wild-type littermates. Further analyses indicated that loss of stromal ER $\alpha$ leads to increased stromal apoptosis, reduced expression of insulin-like growth factor-1 (IGF-1) and FGF10, and increased expression of BMP4. Collectively, we have established the first in vivo prostate stromal and epithelial selective ERaKO mouse models and the results from these mice indicated that stromal fibroblast ERa plays important roles in prostatic branching morphogenesis via a paracrine fashion. Selective deletion of the $E R \alpha$ gene in mouse prostate epithelial cells by probasin-Cre does not affect the regular prostate development and homeostasis.
\end{abstract}

Asian Journal of Andrology (2012) 14, 546-555; doi:10.1038/aja.2011.181; published online 21 May 2012

Keywords: Cre-loxP; estrogen receptor; knockout; prostate; stromal-epithelial interaction

\section{INTRODUCTION}

Prostate growth and development are primarily controlled by androgens. During prostatic development, in the presence of androgens/androgen receptor (AR), ${ }_{1}^{1}$ the urogenital mesenchyme (UGM) directs prostatic epithelial budding and branching morphogenesis through interactions between the urogenital sinus epithelium and UGM. $^{2}$ Conversely, the developing prostatic epithelium induces fibroblasts to undergo smooth muscle differentiation. ${ }^{3}$ In addition to androgens, the prostate can also respond to the stimulation of estrogens. ${ }^{4-6}$ Lower doses of estrogens have been reported to increase prostate weight and prostatic budding. ${ }^{5,6}$ In contrast, higher doses of estrogens permanently suppress the neonatal rat or mouse prostate growth and prostatic branching morphogenesis by reducing testosterone $(\mathrm{T})$ production, suppressing AR expression, and inducing prostatic epithelial regression. ${ }^{7-10}$ Estrogen's actions can be mediated by estrogen receptor alpha $(\mathrm{ER} \alpha)$ and $\mathrm{ER} \beta{ }^{11,12}$ encoded by two distinct genes. Studies conducted with conventional neomycin (Neo) gene knockin and ER knockout (KO) mice suggested that ER $\alpha$, but not ER $\beta$, acts as a dominant receptor of estrogen signaling in males for the development of prostate and for maintenance of normal reproductive functions. ${ }^{13-16}$ However, it remains unclear how ER $\alpha$ functions in different types of prostate cells to affect prostate development. Stromal-epithelial recombination experiments were used to determine $\mathrm{ER} \alpha$ functions in stromal $v s$. epithelial cells. But, there are two major concerns with results obtained from those tissue recombinant experiments: (i) the stromal and epithelial cells used for the recombination experiment may not represent the prostate cell origins; and (ii) the recombinant is implanted under the renal capsule of immunedeficient mouse for a short period of time. Therefore, those experiments may not completely recapitulate the in vivo $\mathrm{ER} \alpha$ roles in prostate developments. To resolve those potential pitfalls, floxed ER $\alpha$ mice were produced using a self-excising ACN (tACE-Cre/Neo) cassette. ${ }^{17}$ We successfully produced the total ER $\alpha \mathrm{KO}$ mice by mating floxed ER $\alpha$ mice with $\beta$-actin-Cre mice (ACTB-ER $\alpha \mathrm{KO}$ ), and proved that deletion of the floxed exon 3 allele can disrupt the reading frame of the ER $\alpha$ transcript resulting in undetectable ER $\alpha$ protein. ${ }^{17}$ Studies of ACTB-ER $\alpha \mathrm{KO}$ male mice demonstrated that ER $\alpha$ is required for maintaining male fertility, prostatic branching morphogenesis and the homeostasis of the prostate. ${ }^{18}$ The mature prostate consists of various cell types including luminal epithelial, basal epithelial, neuroendocrine, smooth muscle, fibroblast, vascular endothelial cells, etc. In

${ }^{1}$ Departments of Urology and Pathology, University of Rochester Medical Center, Rochester, New York 14642, USA and ${ }^{2}$ Sex Hormone Research Center, China Medical University Hospital, Taichung 40402, Taiwan, China

* These authors contributed equally to this work.

Correspondence: Dr SY Yeh (shuyuan_yeh@urmc.rochester.edu)

Received: 27 April 2011; Revised: 12 September 2011; Accepted: 2 December 2011; Published online: 21 May 2012 
the rodent prostate, $\mathrm{ER} \alpha$ is detectable in both epithelial and stromal cells. ${ }^{16,19-21}$ To date, several studies focused on ER $\alpha$ roles in high-dose estrogen-mediated squamous metaplasia (SQM) and carcinogenesis. $^{20,22,23}$ However, no in vivo model has effectively evaluated the roles of epithelial $v s$. stromal fibroblast ER $\alpha$ during normal prostate development. The establishment of the floxed ER $\alpha$ mouse model allows us to selectively delete the $E R \alpha$ gene in a tissue- or temporalspecific manner by breeding with transgenic mice harboring promoter specific $C r e .{ }^{18}$ We now report the generation of the first mouse model that has floxed $E R \alpha$ gene selectively knocked out in stromal fibroblast cells via breeding with fibroblast-specific protein 1-Cre (FSP-Cre) or in epithelial cells via breeding with prostate epithelial-specific probasin-Cre (pes-Cre) to dissect the stromal vs. epithelial ER $\alpha$ function. Our in vivo tissue-selective ER $\alpha \mathrm{KO}$ mouse models demonstrate that stromal fibroblast $\mathrm{ER} \alpha$ plays an important role in prostatic branching morphogenesis via a paracrine-regulatory fashion.

\section{MATERIALS AND METHODS}

Generation of tissue selective ER $\alpha$ KO Mice

To generate FSP-Cre/ER $\alpha^{\mathrm{fl} / \mathrm{fl}}$ and pes-Cre/ER $\alpha^{\mathrm{f} / \mathrm{fl}}$ mice (FSP-ER $\alpha \mathrm{KO}$ and pes-ER $\alpha \mathrm{KO}$ ), we mated floxed ER $\alpha$ homozygous female mice ${ }^{17}$ with FSP-Cre and probasin-Cre transgenic male mice, respectively. a

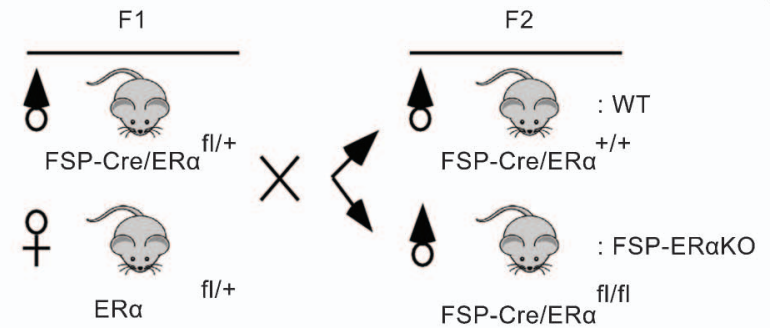

b

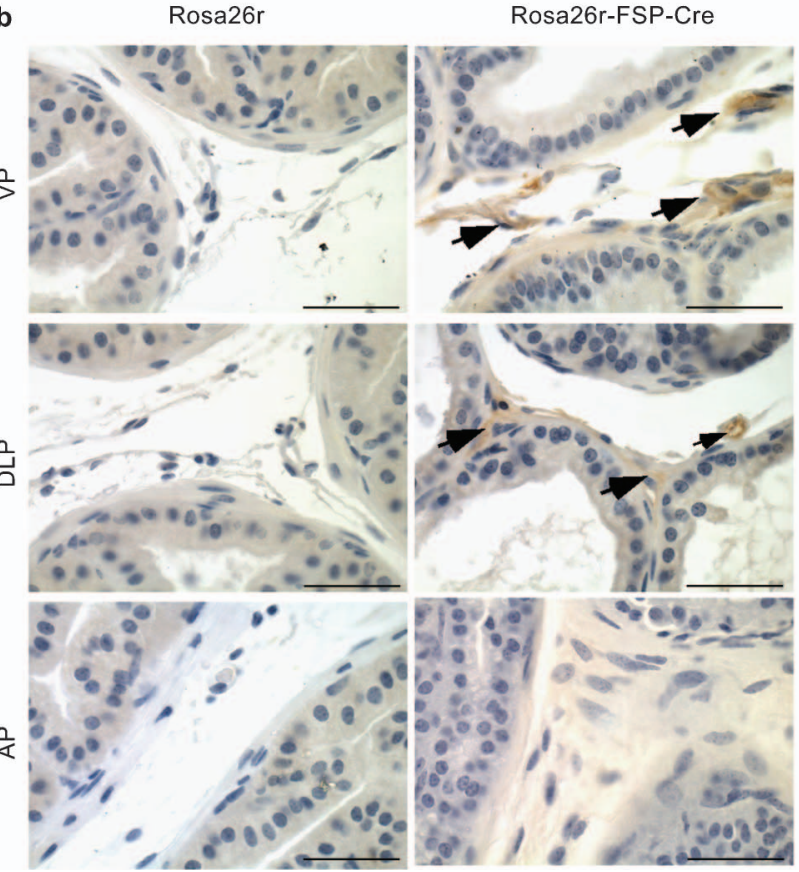

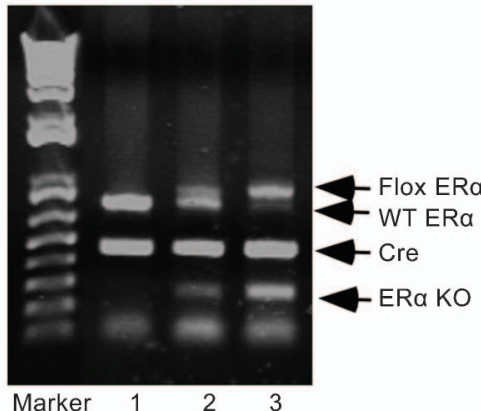

d

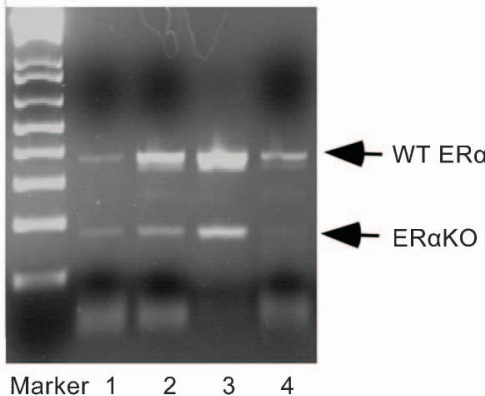

e

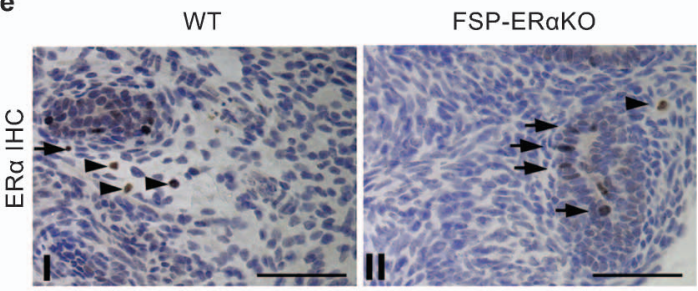

Figure 1 Generation and genotyping of FSP-ER aKO via Cre-loxP strategy. (a) Breeding strategy to generate the tissue-specific ERaKO mice. Floxed ER $\alpha$ homozygous female mice were mated with FSP-Cre transgenic male mice to obtain the FSP-Cre/ER $\alpha^{\mathrm{fl} /+}$ male mice. FSP-Cre/ ER $\alpha^{\mathrm{fl} /+}$ male mice were mated with floxed ER $\alpha$ heterozygote female mice (F1) to obtain the FSP-Cre/ER $\alpha^{+/+}(\mathrm{WT})$ and FSP-Cre/ER $\alpha^{\mathrm{fl} / \mathrm{fl}}(\mathrm{KO})$ mice (F2). (b) FSP-Cre-mediated specific Cre deletion of the floxed stop codon and the expression of $\beta$-galactosidase in the prostate stromal fibroblasts of the Rosa26r-FSP-Cre mice. $\beta$-galactosidase expression mediated by FSP-Cre excision was observed in stromal compartment of VP and DLP (arrows), but not in the stromal compartment of AP. Immunohistochemical staining of $\beta$-galactosidase was detected using $\beta$-gal antibody (Iowa University Hybridoma Bank, lowa city, IA, USA). Scale bar is equal to $25 \mu \mathrm{m}$. (c) Genotypes of tail snips of FSP-Cre/ER $\alpha^{\text {fl/ff }}$ mice. Lane 1: FSP-Cre/ER $\alpha^{+/+}$mice; lane 2: FSP-Cre/ER $\alpha^{\mathrm{fl} /+}$ mice; lane 3: FSP-Cre/ER $\alpha^{\mathrm{fl} / \mathrm{fl}}$ mice. The FSP1 gene promoter is selectively expressed in the fibroblast cells, explaining the presence of the $\mathrm{KO}$ allele in the tail snips of FSP-Cre/ER $\alpha^{\mathrm{fl} /+}$ and FSP-Cre/ER $\alpha^{\mathrm{fl} / \mathrm{fl}}$ mice (lanes 2 and 3 ), in which intervening DNA of floxed ER $\alpha$ allele was partially deleted by FSP-Cre recombinase. The size of deleted ER $\alpha$ allele was reduced compared to WT and floxed ER $\alpha$. The size of floxed ER $\alpha$, WT ER $\alpha$, ER $\alpha$ KO allele, and Cre are $881 \mathrm{bp}, 741 \mathrm{bp}, 223 \mathrm{bp}$, and $411 \mathrm{bp}$, respectively. (d) Detection of ER $\alpha$ transcripts in the various adult male reproductive organs was performed by RT-PCR using primers that span exons I and III of the ER a gene in the FSP-ERaKO mice. Lane 1: prostate; lane 2: epididymides; lane 3: efferent ducts; lane 4: testes. In FSP-ER $\alpha$ KO mice; both WT ER $\alpha$ band and the truncated transcript band (deletion of exon 3 ) can be detected in different male reproductive organs due to floxed $E R \alpha$ gene $\mathrm{KO}$ in fibroblasts. (e) The expression of ER $\alpha$ in the 1-week-old FSP-ER $\alpha$ KO and WT VPs was determined by IHC. Arrows show positive staining of ER $\alpha$ in the epithelial cells. Arrowheads show positive staining of ER $\alpha$ in the stromal cells. Scale bar is $100 \mu \mathrm{m}$; AP, anterior prostate; DLP, dorso-lateral prostate; ER, estrogen receptor; FSP, fibroblast-specific protein; IHC, immunohistochemistry; KO, knockout; RT-PCR, real-time PCR; VP, ventral prostate; WT, wild type. 
FSP-Cre mice were received from Drs H. L. Moses and N. A. Bhowmick (Vanderbilt-Ingram Cancer Center, Nashville, TN, USA) and the probasin-Cre mice were obtained from National Cancer Institute (Bethesda, MD, USA). $\mathrm{ER} \alpha^{\mathrm{fl} / \mathrm{fl}}$ mice were created through a collaboration with Dr S. Radovick and Dr A. Wolf (Johns Hopkins University, Baltimore, MD, USA). ${ }^{17,18}$ After two generations of mating, FSP-ER $\alpha$ KO (Figure 1a) and pes-ER $\alpha$ KO (Figure 4a) mice were developed. Genomic DNA was isolated from tail biopsies and used as a template for PCR genotyping. Genotyping and primers were listed in our previously publications. ${ }^{17,18}$ The Rosa26r reporter mice have the lac $Z$ gene inserted into the ubiquitously expressed Rosa locus. This locus is preceded by a transcriptional stop cassette flanked by two loxP sites. When Cre-recombinase is expressed, $\beta$-Gal activity can be observed in target organs. ${ }^{23,24}$ We bred Rosa26r-FSP-Cre compound mice to detect the Cre activity and expression pattern of FSP-Cre mice. The ACTB-ER $\alpha \mathrm{KO}$, a whole-body ER $\alpha \mathrm{KO}$, mice were generated by breeding flox $\mathrm{ER} \alpha$ mice with $\beta$-actin-Cre mice as previously described. ${ }^{17,18}$ All animal procedures were approved by the Animal Care and Use Committee of the University of Rochester Medical Center, in accordance with National Institutes of Health guidelines.

\section{Tissue dissection and prostatic ductal tip count}

Mice were first anesthetized to collect serum for hormone analysis and then killed by $\mathrm{CO}_{2}$ asphyxiation. After centrifugation, the serum was frozen at $-70{ }^{\circ} \mathrm{C}$ until assayed. The genital tracts of the animals were exposed by a lower abdominal incision. The individual organs were then microdissected, weighed, photographed and frozen for further analysis, or fixed in formalin for subsequent histological examination. For the ductal tip count experiment, microdissected ventral prostate (VP), dorso-lateral prostate (DLP) and anterior prostate (AP) were incubated in Hank's buffer containing $1 \%$ collagenase at $37^{\circ} \mathrm{C}$ for $1 \mathrm{~h}$ to digest and remove stromal compartment. The number of ductal tips was then counted under a dissecting microscope.

\section{Hormone radioimmunoassay}

All male mice were housed individually for 1 week before collection of serum for hormone analysis. Serum $\mathrm{T}$ was determined using a $\mathrm{T}$ double antibody radioimmunoassay kit (Diagnostic System Laboratories, Inc., Webster, TX, USA). The lowest detectable T concentration is $2.0 \mathrm{pg} \mathrm{ml}^{-1}$. Animals used in the hormone studies were approximately 3 months of age.

\section{Sperm counting}

The mouse epididymides were chopped into small pieces in $1.5 \mathrm{ml}$ RPMI media, incubated for $40 \mathrm{~min}$ at $37^{\circ} \mathrm{C}$ to release the sperm, and then diluted for counting the total sperm numbers per epididymis.

\section{Immunohistochemistry (IHC), immunofluorescent staining and} terminal transferase-mediated DNA end labeling (TUNEL) assay IHC and immunofluorescent staining were carried out as described previously. ${ }^{17,18}$ Sections were incubated with the following antibodies and dilutions: anti- $\beta$-gal antibody (40-1A, $1: 400)$, anti-ER $\alpha$ (MC-20, $1: 400)$, anti-AR (N-20, 1:400), anti-Ki67 (NCL-Ki67p, 1:1000), anti-vimentin (LN-6, 1:200), anti-SM $\alpha$-actin (1A4, 1:400), antidesmin (DE-U-10, 1:300), anti-heavy chain myosin (G-4, 1:500) and anti-pan-cytokeratin (H-240, $1: 200)$ in phosphate buffered saline containing $3 \%$ bovine serum albumin overnight at $4{ }^{\circ} \mathrm{C}$. For IHC, the tissue slides were incubated with $1: 300$ diluted biotinylated secondary antibody (Vector Laboratories, Burlingame, CA, USA) and ABC solution (Vector Laboratories), then stained using AEC (DAKO,
Carpenteria, CA, USA). Mayer's hematoxylin was used for a nuclear counterstain. Negative controls were incubated without primary antibody. For immunofluorescent staining, the tissue slides were incubated with 1:100 Texas red-conjugated goat anti-mouse IgG or fluorescein isothiocyanate-conjugated goat anti-rabbit IgG (ICN, Costa Mesa, CA, USA). Stained slides were mounted with mounting media containing $4^{\prime}$-6-Diamidino-2-phenylindole and visualized with a fluorescent microscope. The apoptosis in paraffin embedded tissue was detected by the TUNEL assay using In situ Cell Death Detection Kit (Roche, Indianapolis, IN, USA) following the manufacturer's instructions. 4'-6-Diamidino-2-phenylindole-stained cells were counted under a fluorescent microscope from at least six randomly selected fields. Cells positive for TUNEL staining were counted in the same field. At least six fields from each lobe of prostates were analyzed. The apoptotic index was determined by dividing the number of TUNEL positive cells by the total numbers of cells in all six fields.

\section{RNA extraction and RT-PCR}

Total RNA was extracted and purified using Trizol (Invitrogen, Carlsbad, CA, USA) and RT-PCR has been described previously. ${ }^{18,25}$ Briefly, $3 \mu \mathrm{g}$ total RNA from wild-type (WT) or tissue-specific ER $\alpha \mathrm{KO}$ prostates was subjected to reverse transcription using Superscript III (Invitrogen, Carlsbad, CA, USA). The RT-PCR was performed with first-strand cDNA, specific gene primers and SYBR Green PCR Master Mix (Biorad, Hercules, CA, USA). The Q-PCR cycle was performed as follows: $94^{\circ} \mathrm{C}$ for $3 \mathrm{~min}, 40$ cycles of $94^{\circ} \mathrm{C}$ for $30 \mathrm{~s}, 60^{\circ} \mathrm{C}$ for $30 \mathrm{~s}$ and 72 ${ }^{\circ} \mathrm{C}$ for $30 \mathrm{~s}$ on an iCycler iQ Multi-color RT-PCR detection system (Biorad). Primer sequences for mouse genes have been described previously. ${ }^{18}$ The primer sequences for rat genes: FGF7, sense, $5^{\prime}$ GCTTCCACCTCGTCTGTCTTG-3' ; antisense, 5' -CCCTTTCACTTTGCCTCGTTTG-3' . FGF10, sense 5' -CTGTTGCTGCTTCTTGTTG$3^{\prime}$; antisense, $5^{\prime}$-TTCCACTGATGTTATCTCTAGG-3' . IGF-1, sense, 5' -CTGCTGCGTGGTGGTCTG-3'; antisense, 5' -CATTGTATGGCTATCTGTCTTGGC-3'. BMP4: sense, 5'-TGATACCTGAGACCGGGAAG-3'; antisense, 5'-AGCCGGTAAAGATCCCTCAT-3'. BMP7, sense, 5'-TCCGGTTTGATCTTTCCAAG-3'; antisense, 5' TGGTGGCTGTGATGTCAAAT-3'. $\quad \beta$-actin: sense, $5^{\prime}$-TATCGGCAATGAGCGGTTCC-3'; antisense, 5' -TATCGGCAATGAGCGGTTCC-3'. Each sample was run in triplicate for each Q-PCR. Data were analyzed using iCycler iQ software (Biorad).

\section{Statistical analyses}

Values were expressed as mean \pm standard deviation (s.d.). We used the $t$-test to compare values among the two groups. Calculated $P$ values were two-sided, and $P<0.05$ was considered statistically significant.

\section{RESULTS}

\section{Generation of FSP-ER $\alpha$ KO Mice}

To address the role of stromal fibroblast ER $\alpha$ in normal prostate development, we generated mice with conditional deletion of the $E R \alpha$ gene in stromal fibroblast cells by mating floxed $E R \alpha$ female mice with male mice expressing Cre recombinase driven by the FSP1 promoter (Figure 1a). FSP1 gene expression is first detected by in situ hybridization at embryonic day 8.5 as a postgastrulation event, and is associated with cells of mesenchymal origin or of fibroblastic phenotype. ${ }^{26-28}$ Selective Cre-mediated recombination exerted by the FSPCre transgene has been observed in stromal fibroblast cells throughout the mouse, including the prostate, forestomach and skin. ${ }^{29}$ The Rosa26r reporter mice have the lac $Z$ gene inserted into the ubiquitously expressed Rosa locus, which is preceded by a transcriptional 
stop cassette flanked by two loxP sites. When Cre-recombinase is expressed, this stop cassette is deleted and $\beta$-galactosidase activity can be observed in target organs. ${ }^{23,24}$ We examined FSP-Cre-mediated loxP site recombination within the mouse prostates in Rosa26rFSPCre mice. Figure $\mathbf{1 b}$ showed that FSP-Cre specifically expressed in the prostatic stromal compartment with strong expression in the VP and DLP (arrows), marginal expression in the AP, and was not detectable in the prostatic epithelial cells.

To verify $E R \alpha$ gene deletion in the FSP-ER $\alpha$ KO mice, pups were genotyped for floxed $\mathrm{ER} \alpha$, WT ER $\alpha, \mathrm{ER} \alpha \mathrm{KO}$ allele and the FSP-Cre transgene (Figure 1c). Deletion of ER $\alpha$ exon III was confirmed by detection of truncated mRNA transcripts using a pair of PCR primers located on exons II and IV of the ER $\alpha$ gene. Our data showed truncated $\mathrm{ER} \alpha$ transcripts within the prostate, epididymis, efferent ducts and testis of the FSP-ER $\alpha \mathrm{KO}$ mice (Figure 1d).

$\mathrm{ER} \alpha$ deletion in FSP-ER $\alpha \mathrm{KO}$ prostates was further validated by IHC in the prostates of 1-month-old mice. We found that ER $\alpha$ expression was positive in epithelial cells in VPs of WT and FSP$\mathrm{ER} \alpha \mathrm{KO}$ mice (Figure 1e, I, arrows). However, ER $\alpha$ expression was dramatically reduced in the stromal compartments of FSP-ER $\alpha \mathrm{KO}$ VPs (Figure 1e, II vs. I, arrowhead) as compared to that of WT littermates.

\section{Normal genital tract development and fertility in adult FSP-ER $\alpha$ KO males}

Comparing 3-month-old FSP-ER $\alpha$ KO males to WT littermates, histological analyses demonstrated that there were no phenotype alterations in the male reproductive system including testes, epididymides (Figure 2a), or efferent ducts and seminal vesicles (data not shown). FSP-ER $\alpha$ KO testes consisted of compact seminiferous tubules. The atrophic and degenerating seminiferous tubules present in the ACTB-ER $\alpha$ KO were not observed in the FSP-ER $\alpha$ KO mice. ${ }^{18}$ The FSP-ER $\alpha \mathrm{KO}$ epididymis also appeared normal as compared to those of WT mice (Figure 2a). There was no statistical difference in the epididymal sperm number count between FSP-ER $\alpha$ KO and WT mice (Figure 2b). Furthermore, in contrast to the infertility of ACTB$\mathrm{ER} \alpha \mathrm{KO}$ mice, when mating WT and FSP-ER $\alpha \mathrm{KO}$ males with fertile B6 females, we found that there were no statistical differences in litter sizes among those matings (Figure 2c). Moreover, the serum T level in FSP-ER $\alpha$ KO males is similar to the levels in WT males at 3 months of age (Figure 2d). Together, our data indicate that the serum $\mathrm{T}$ levels, the development of testes and epididymides, and male fertility remain normal in FSP-ER $\alpha$ KO males.

\section{Reduced prostate branching morphogenesis and weight in FSP-ERaKO mice}

Our previous report ${ }^{18}$ of the total ER $\alpha$ KO (ACTB-ER $\alpha$ KO) mice showed that $\mathrm{ER} \alpha$ is involved in prostatic branching morphogenesis; however, it is unclear as to whether epithelial or stromal ER $\alpha$ plays a dominant role in prostatic branching morphogenesis. Results of comparing microdissected prostates from 3-monthold mice, demonstrated the reduced number of ductal tips derived from prostatic branching of adult ACTB-ER $\alpha$ KO prostates (Figure 3a, ACTB-ER $\alpha$ KO vs. WT, $* * P<0.001$ in both VP and DLP). Compared to WT mice, FSP-ER $\alpha$ KO mouse prostates had a significantly reduced branching morphogenesis (Figure 3a, FSP-ER $\alpha$ KO $v s$. WT, $* * P<0.01$ in VP; $* P<0.001$ in DLP). It has been known that APs, also called coagulating glands, are less similar to human prostate structure and development. Indeed, we did not observe a difference in branching morphogenesis in a
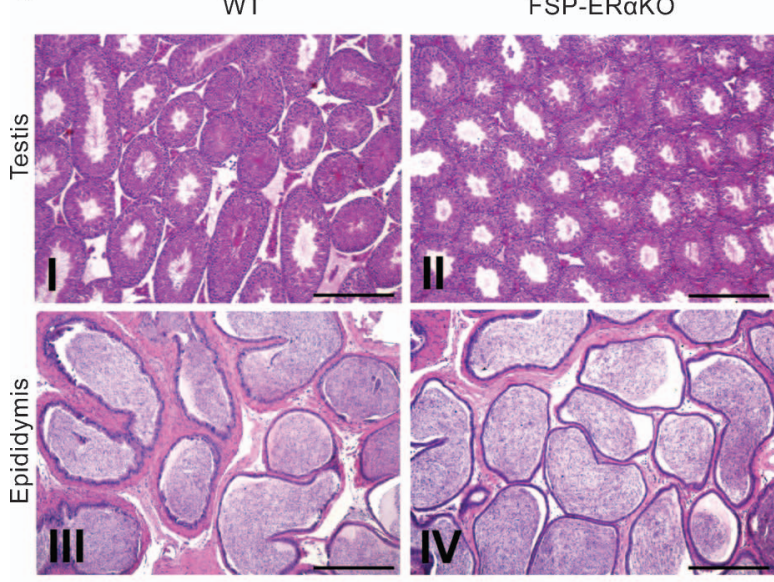

b
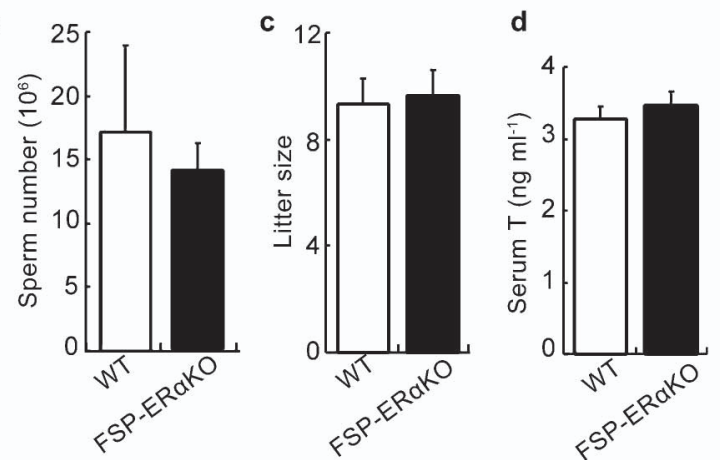

Figure 2 Histological analysis of reproductive organs and fertility test in WT (FSP$\mathrm{Cre} / \mathrm{ER}^{+/+}$) and FSP-ER $\alpha$ KO (FSP-Cre/ER $\alpha^{\mathrm{fl} / \mathrm{fl}}$ ) adult males. (a) Histological analyses of testes and epididymides from adult WT and FSP-ER $\alpha$ KO males at the age of 3-month. FSP-ER $\alpha$ KO testes appeared normal and consisted of compact seminiferous tubules (II vs. I). Scale bar is $400 \mu \mathrm{m}$. The cauda epididymides from FSPER $\alpha$ KO males contained sperm comparable to WT mice (IV vs. III). Scale bar is 100 $\mu \mathrm{m}$. (b) The sperm counts of adult FSP-ER $\alpha K O$ VP and WT littermates. Results are presented as mean \pm s.d. $(n=5)$. (c) To assess fertility, 3-month-old WT or FSPER aKO males were mated with WT females. Pups per litter from each mating were compared and found to be similar. Results are presented as mean \pm s.d. $(n=5)$. (d) The serum T levels in the adult FSP-ER $\alpha$ KO males. The serum samples were from 12 - to 14-week-old males. Results are presented as mean \pm s.d. $(n=4)$. ER, estrogen receptor; FSP, fibroblast-specific protein; IHC, immunohistochemistry; $\mathrm{KO}$, knockout; T, testosterone; VP, ventral prostate; WT, wild type.

the APs of FSP-ER $\alpha \mathrm{KO}$ and WT mice, which is consistent with results in the ACTB-ER $\alpha$ KO mice. ${ }^{18}$ Consistently, we observed the reduced prostate weights in FSP-ER $\alpha$ KO mice (Figure $3 \mathbf{b}$ ). Together, our findings from FSP-ER $\alpha$ KO provided direct evidence that prostate fibroblast $\mathrm{ER} \alpha$ plays important roles in prostatic branching morphogenesis.

\section{Increased stromal apoptosis in the FSP-ER $\alpha \mathrm{KO}$ prostates}

The mouse prostate undergoes extensive branching morphogenesis and $85 \%$ of the adult number of ductal tips and branch points are formed during the first 15 days after birth, ${ }^{30}$ suggesting that prostate cell proliferation rate is high during the neonatal stages. As we observed reduced branching morphogenesis and prostate weights in the FSP-ER $\alpha$ KO mice (Figure 3a and $\mathbf{b}$ ), we were interested in comparing the proliferation activity of the VP between FSP-ER $\alpha$ KO and WT mice at 1-week-old (Figure 3c). IHC results of Ki67 expression suggested that there was no difference in either epithelial proliferation (Figure 3d, arrows) or 
a

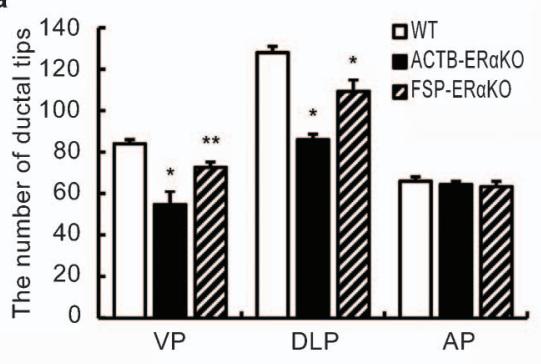

c

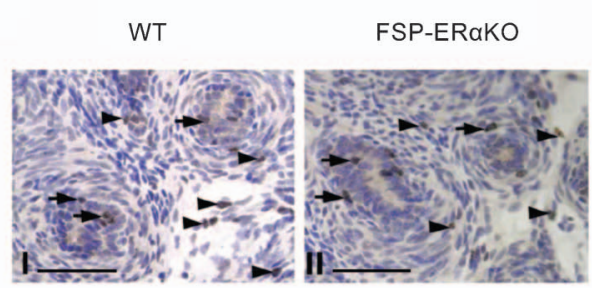

b
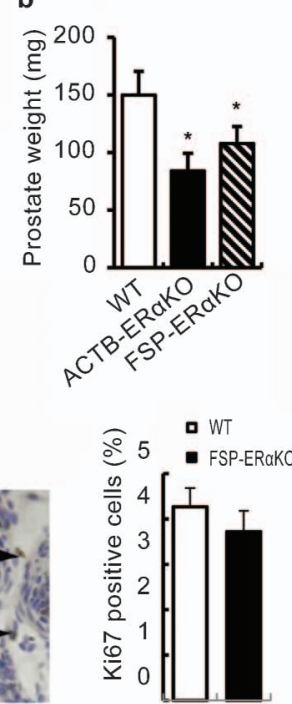

d

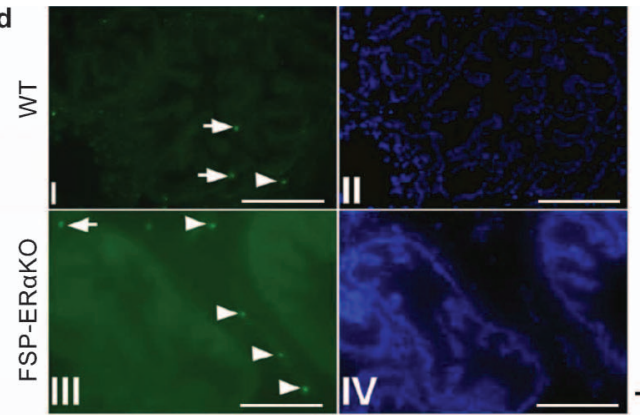

e
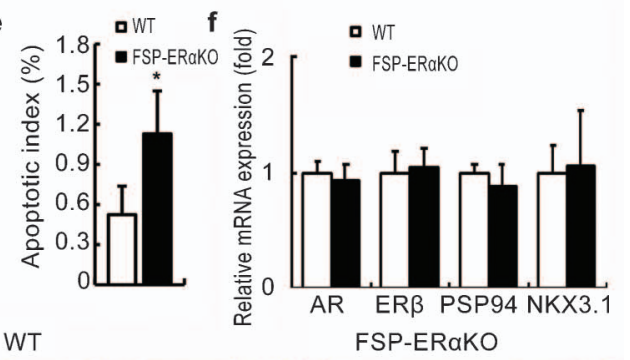

9 WT FSP-ERaKO
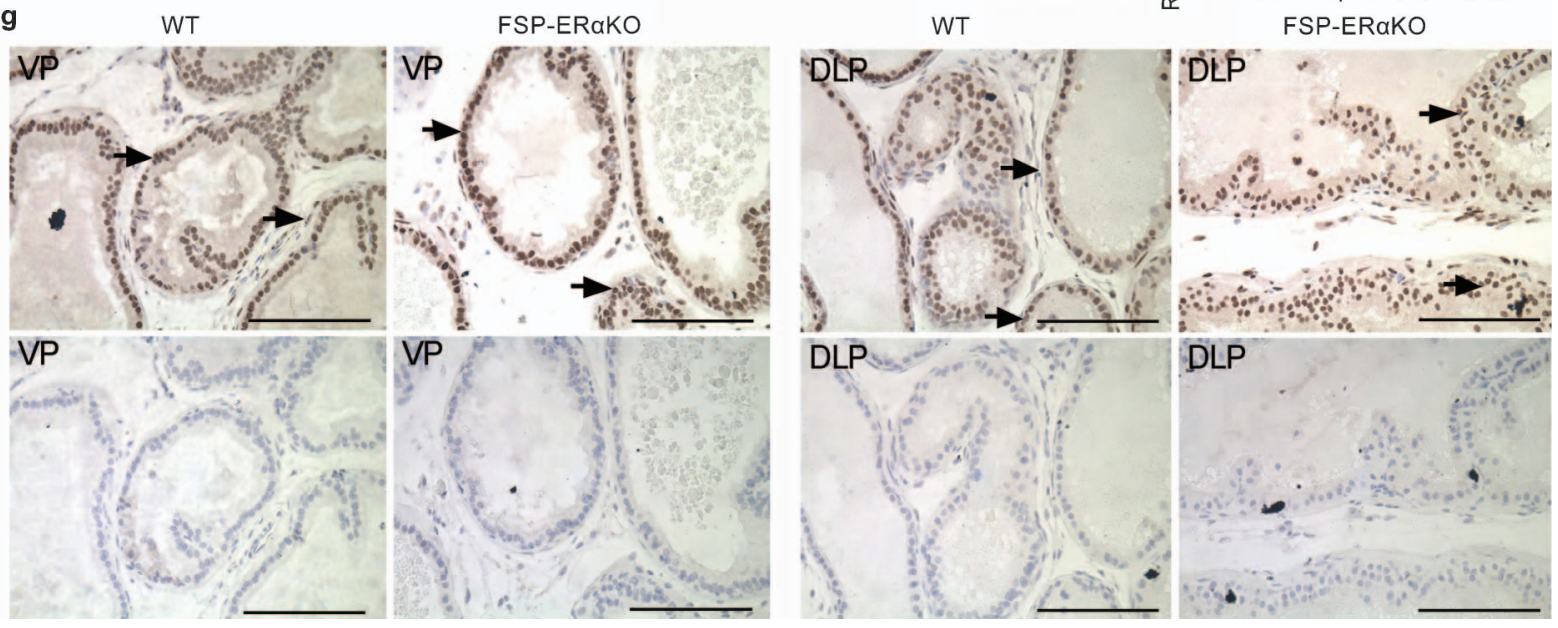

Figure 3 Loss of stromal ER $\alpha$ leads to the defective ductal morphogenesis, reduced prostate weight, and increased apoptosis. (a) The total number of ductal tips in ACTB-ER $\alpha K O$, FSP-ER $\alpha K O$ and WT littermates of 14-week-old. There are significantly reduced ductal tips in VPs and DLPs, but not in APs, of both ACTB-ER $\alpha$ KO and FSP-ER $\alpha$ KO mice as compared to prostates of WT littermates. ${ }^{*} P<0.01,{ }^{*} P<0.001 \mathrm{vs}$. WT littermates (statistically significant by ANOVA analysis). Results are mean \pm s.d. ( $n=5$ ). (b) The comparison of prostate weights of FSP-ER aKO and WT males at 3-month-old. $* P<0.05$ vs. WT. (c) The IHC detection of Ki67 expression in the VPs of FSP-ER aKO and WT males at 1-week-old. Arrows show positive staining of Ki67 protein in the epithelial cells. Arrowheads show positive staining of Ki67 in the stromal cells. The Ki67 proliferation index was scored as the percentage of Ki67-positive cells. (d, e) The apoptosis assay in the adult WT and FSP-ER aKO VPs. (d) The apoptosis activities are detected by TUNEL assay. Arrows show TUNEL-positive staining in the epithelial cells. Arrowheads show TUNEL-positive staining in the stromal cells. (e) The apoptotic index was scored as the percentage of TUNEL-positive cells. $* P<0.05$ vs. WT littermates (statistically significant by unpaired $t$-test). Results are mean \pm s.d. ( $n=4$ ). (f) RT-PCR was used to compare the expression of AR, AR downstream target genes, and ER $\beta$ in adult FSP-ERaKO and WT littermates VP. Assays were performed on RNA from individual prostate lobes. The data are presented as mean \pm s.d. of samples collected from three different pairs of WT and FSP-ERaKO mice. Note that there is no difference in the mRNA expression of AR, ER,$P S P 94$ and NKX3.1 between the adult VPS of FSP-ER $\alpha$ KO males and WT littermates. (g) IHC was applied to detect the AR expression in the adult FSP-ER aKO and WT littermate prostates. Arrows show positive AR staining in the epithelial cells. Scale bar is $100 \mu \mathrm{m}$. AP, anterior prostate; DLP, dorso-lateral prostate; ER, estrogen receptor; FSP, fibroblast-specific protein; IHC, immunohistochemistry; KO, knockout; RT-PCR, real-time PCR; T, testosterone; TUNEL, terminal transferase-mediated DNA end labeling; VP, ventral prostate; WT, wild type.

stromal proliferation (Figure 3d, arrowheads) between neonatal FSPER $\alpha$ KO and WT VPs. We also did not observe any significant proliferation difference between the adult FSP-ER $\alpha \mathrm{KO}$ and WT prostates (data not shown). As there was no significant change in proliferative rate of neonatal and adult mouse prostate, we examined the apoptotic activities in the FSP-ER $\alpha \mathrm{KO}$ and WT prostates. As expected, apoptosis occurred rarely in 1-week-old WT and FSP-ER $\alpha$ KO mouse prostates (data not shown). In adult mouse prostates, TUNEL assay indeed showed that there was a significantly increased stromal apoptosis in the FSPER $\alpha$ KO males (Figure 3d, III vs. I, arrowheads, VP data were shown), suggesting that the increased apoptotic rate contributed to the reduced branching morphogenesis in the FSP-ER $\alpha$ KO mice. The quantitative apoptotic index is shown in Figure 3e.

The expressions of AR, AR target genes and ER $\beta$ are normal in the FSP-ERaKO prostates

It has been known that $\mathrm{AR}$ and $\mathrm{ER} \beta$ could affect prostate development and homeostasis. ${ }^{31-36}$ Therefore, we checked whether there were changes of AR and ER $\beta$ expression or functions in FSP-ER $\alpha$ KO prostates.

The expression of AR was detected via both IHC and Q-PCR methods. Our IHC results indicated that AR was located predominantly in the nuclei of luminal epithelial cells and there was no obvious 
difference in AR expression levels or nuclear-cytosol distribution between adult FSP-ER $\alpha$ KO and WT VP and DLP (Figure 3g). Consistently, Q-PCR data suggested there was no significant change of AR mRNA in the FSP-ER $\alpha$ KO prostates (Figure 3f). AR target genes, PSP94 and NKX3.1, markers of prostate cytodifferentiation, also expressed normally in FSP-ER $\alpha$ KO prostates as compared to WT littermates (Figure 3f). Furthermore, we did not observe any significant change in the expression of ER $\beta$ in the FSP-ER $\alpha \mathrm{KO}$ prostates (Figure 3f). Together, these observations suggest that the defects of prostate ductal morphogenesis in the FSP-ER $\alpha$ KO prostates is not due to the alterations of serum $\mathrm{T}$ level (Figure 2d), or expressions of AR, AR target genes and $E R \beta$ (Figure $3 \mathbf{f}$ and $\mathbf{g}$ ).

\section{Generation and genotyping of pes-ERaKO mice}

In addition to the stromal compartment, it is argued that prostate epithelial cells also express ER $\alpha$ and the epithelial ER $\alpha$ may contribute to the prostate development. To address this, it is important to use prostate epithelial cell-specific Cre to knock out the ER $\alpha$ gene. The similar breeding strategy of producing FSP-ERaKO mouse was applied to generate the pes-ER $\alpha \mathrm{KO}$ mice (Figure 4a). The promoter of probasin is well characterized and widely applied in many animal models. ${ }^{37-39}$ The expression of probasin Cre (PB-Cre) is prostatic epithelial-specific and is postnatal and gradually increased with highest expression in the lateral lobe, followed by the VP, and then the DP and AP. ${ }^{37,38}$ Therefore, PB-Cre can specifically knock out the floxed $E R \alpha$ gene in prostate epithelial cells (pes-ER $\alpha \mathrm{KO}$ ).

To verify $E R \alpha$ gene deletion in the pes-ER $\alpha$ KO mice, young mice were genotyped for floxed $\mathrm{ER} \alpha$ allele and $\mathrm{PB}-\mathrm{Cre}$ transgene (Figure $4 \mathbf{b}$ ). Since the Cre recombinase only expressed in the adult prostate epithelial cells, there is no $\mathrm{ER} \alpha \mathrm{KO}$ band detected in the tail snips of these pes-ER $\alpha \mathrm{KO}$ mice (Figure $4 \mathbf{b}$, lane 3 ). In 3-month-old pes-ER $\alpha$ KO mice, only the prostates revealed a recombined 223-bp DNA fragment of the ER $\alpha \mathrm{KO}$ allele (Figure 4c, lane 4), indicating that PB-Cre selectively disrupts $\mathrm{ER} \alpha$ in the prostates.

Although ER $\alpha$ protein expression is elevated in VP and DLP lobes in prostate cancer, or in estrogen-stimulated prostate proliferation and SQM, we and other investigators have found that $\mathrm{ER} \alpha$ protein can be detected in VP and DLP, with a more stronger expression in AP of mice prior to any development of prostate diseases. Therefore, we compared the ER $\alpha$ expression in the AP of adult pes-ER $\alpha \mathrm{KO}$ and WT littermates. ER $\alpha$ was mainly detected in the AP epithelial cells of WT mice (Figure 4d, left panel) and was rarely detected in pes$\mathrm{ER} \alpha \mathrm{KO}$ AP (Figure 4d, right panel), which indicates that $\mathrm{ER} \alpha$ is selectively ablated in pes-ER $\alpha$ KO prostate epithelial cells.

\section{Genital tract phenotype, fertility and prostatic branching morphogenesis in adult pes-ERaKO males}

Similar to FSP-ER $\alpha$ KO males, 3-month-old pes-ER $\alpha$ KO males did not exhibit any abnormalities in terms of the genital tract, sperm number and fertility (Figure 5a-c), suggesting that a postnatal depletion of epithelial $\mathrm{ER} \alpha$ in the prostates did not affect the male reproductive system or fertility. Furthermore, pes-ER $\alpha$ KO prostates did not display any difference in weight and branching morphogenesis when compared to WT prostates (Figure 5d and e). Consistently, there was no significant changes in the expression of genes involved in prostatic branching morphogenesis (BMP4, BMP7 and Shh), prostatic cytodifferentiation markers (PSP94 and NKX3.1), or smooth muscle marker $(S M-\alpha$-actin) between 3 -month-old pes-ER $\alpha \mathrm{KO}$ and WT prostates (Figure 5f). Further comparison between pes-ER $\alpha \mathrm{KO}$ and WT a
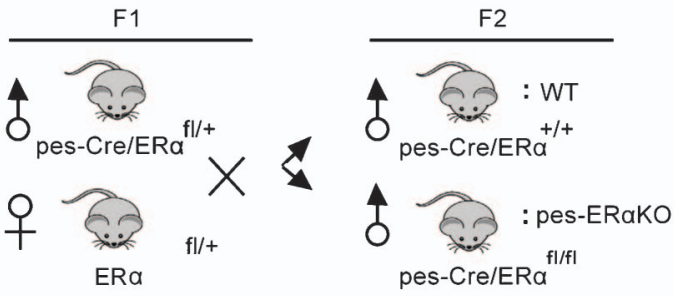

b

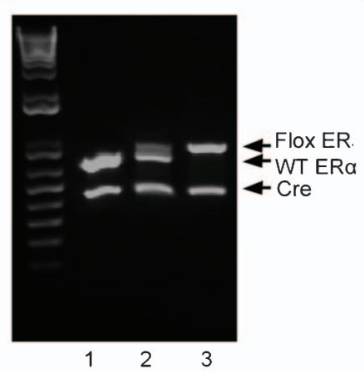

c

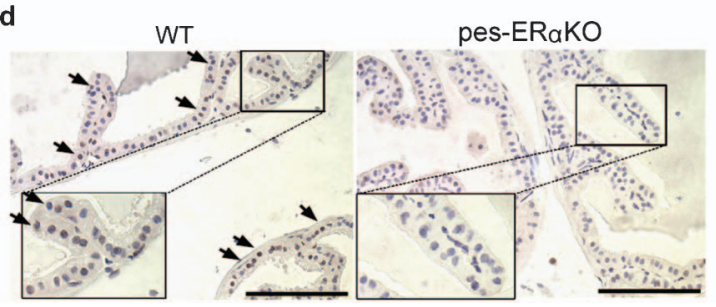

Figure 4 Generation and genotyping of pes-ER $\alpha$ KO male mice via Cre-loxP strategy. (a) Breeding strategy to generate the pes-ER $\alpha$ KO mice. ER $\alpha^{\text {fl/fl }}$ female mice were mated with probasin-Cre transgenic male mice to obtain the pes-Cre/ $\mathrm{ER} \alpha^{\mathrm{fl} /+}$ male mice $(\mathrm{F} 1)$. pes-Cre/ER $\alpha^{\mathrm{fl} /+}$ male mice were mated with $\mathrm{ER} \alpha^{\mathrm{fl} /+}$ heterozygous female mice to obtain the pes-Cre/ER $\alpha^{+/+}$(WT) and pes-Cre/ $E R \alpha^{\mathrm{fl} / \mathrm{fl}}$ (pes-Cre/ER $\alpha \mathrm{KO}$ ) mice (F2). (b) Genotypes of tail snips of pes-Cre/ $E R \alpha^{f l / f \mid}$ mice. Lane 1: pes-Cre/ER $\alpha^{+/+}$mice, the size of WT ER $\alpha$ and Cre was 741 and $411 \mathrm{bp}$, respectively; lane 2: pes-Cre/ER $\alpha^{\mathrm{fl} /+}$ mice; lane 3: pes-Cre/ $\mathrm{ER} \alpha^{\mathrm{fl} / f \mathrm{l}}$ mice. Probasin promoter will drive Cre specifically expressed in the prostatic epithelial cells in the adult stages, therefore, there is no $\mathrm{KO}$ allele present in the tail snips of pes-Cre/ER $\alpha^{\mathrm{fl} /+}$ mice and pes-Cre/ER $\alpha^{\mathrm{fl} / f l}$ mice (lanes 2 and 3). (c) Genotyping of various adult male reproductive organs of pes-ER $\alpha$ KO mice. Only the genomic DNA from the prostates of pes-ER $\alpha$ KO mice showed the ER $\alpha \mathrm{KO}$ allele. Lane 1: testes; lane 2: epididymides; lane 3: efferent ducts; lane 4: prostates. (d) The expression of ER $\alpha$ in the APs of adult pes-ER $\alpha K O$ and WT was determined by IHC. Arrows show positive staining of ER $\alpha$ in the epithelial cells of WT mice. Scale bar is $100 \mu \mathrm{m}$. (Enlarged inserts are presented.) AP anterior prostate; ER, estrogen receptor; IHC, immunohistochemistry; KO, knockout; pes-ER $\alpha$ KO, prostate epithelial cell-specific ER $\alpha \mathrm{KO}$; WT, wild type.

prostates was conducted on 12-month-old mice, since PB-Cre efficiency is believed to reach $100 \%$ at that age. ${ }^{38}$ Comparisons revealed that pes-ER $\alpha \mathrm{KO}$ and WT prostates have similar gene expression profiles and branching morphogenesis (data not shown). Taken together, our findings suggest that stromal $\mathrm{ER} \alpha$, but not epithelial $\mathrm{ER} \alpha$, is involved in prostatic branching morphogenesis and homeostasis of prostate.

\section{Gene profile comparison in the WT, FSP-ER $\alpha$ KO and pes-ER $\alpha$ KO} prostates

The prostatic branching morphogenesis is a complex interaction between prostate epithelial and mesenchymal cells regulated by time-specific and region-specific expression of signaling molecules. ${ }^{40}$ Our previous studies found selective upregulation of BMP4 expression, 


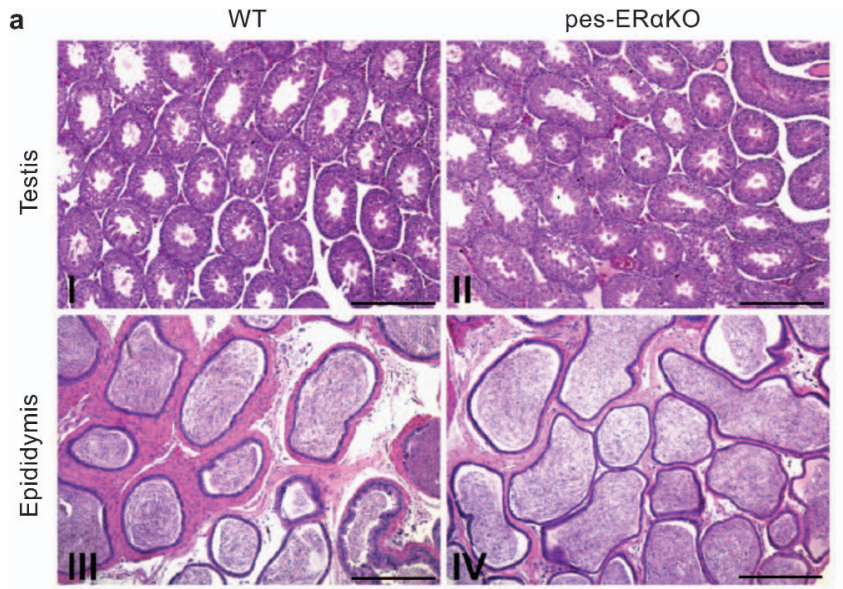

b

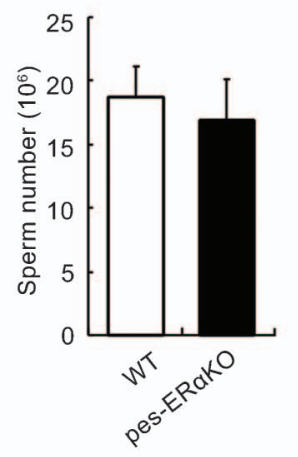

f $\quad$ f WT

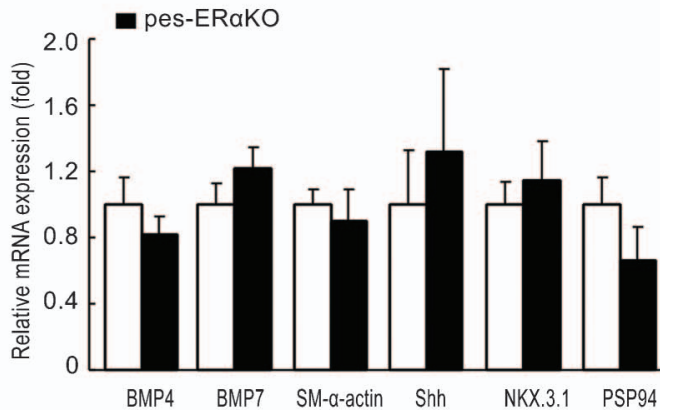

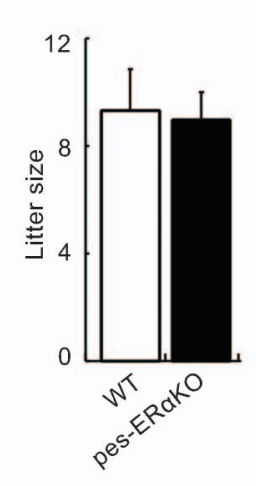

C d
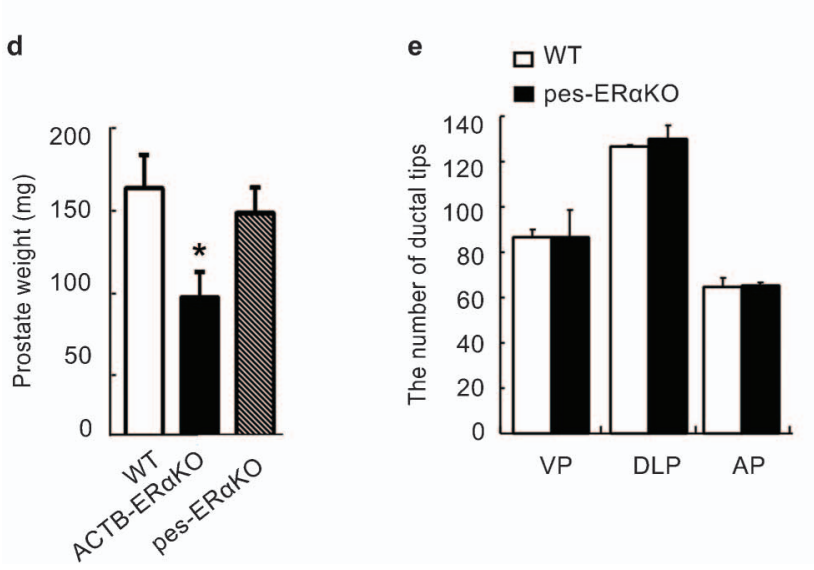

Figure 5 Histological analyses of testes and epididymides, fertility test and prostatic morphogenesis in the pes-ERaKO adult males. (a) Histological analyses of testes and epididymides from WT and pes-ER $\alpha$ KO males at 3-month-old. pes-ER $\alpha$ KO testes appeared normal and consisted of compact seminiferous tubules. Scale bar is $400 \mu \mathrm{m}$. The cauda epididymides from pes-ER aKO males contained sperm comparable to WT mice. Scale bar is $100 \mu \mathrm{m}$. (b) The comparison of the sperm count between adult pes-ERaKO and WT littermates. Results are presented as mean \pm s.d. ( $n=5$ ). (c) Assess fertility of ERaKO males. Pup numbers per litter from WT females mating with WT or pes-ERaKO males were compared and found to be not significantly different. Results are presented as mean \pm s.d. ( $n=5$ ). (d-e) The prostate weight and the total number of ductal tips in the pes-ER $\alpha \mathrm{KO}$ and WT littermates shows no difference $(n=5) . * P<0.05$ vs. WT littermates. (f) The comparison of the expression levels of the genes involved in prostatic branching morphogenesis and prostate differentiation between pes-ERaKO and WT littermates by real-time Q-PCR. Assays were performed on RNA from the VPs of each individual mouse and then the gene expression results were averaged. 18S rRNA was used as an internal control. Note that the genes involved in the ductal morphogenesis and prostate differentiation showed no significant difference between WT and pes-ERaKO mice. ER, estrogen receptor; FSP, fibroblastspecific protein; KO, knockout; pes-ERaKO, prostate epithelial cell-specific ER $\alpha$ KO; Q-PCR, quantitative PCR; VP, ventral prostate; WT, wild type.

but not BMP7, in the ACTB-ER $\alpha$ KO prostates. ${ }^{18}$ As BMP4 is a mesenchymal factor that inhibits prostatic branching morphogenesis, ${ }^{41}$ the upregulation of BMP4 in the ACTB-ER $\alpha$ KO prostates could directly contribute to the reduced branching morphogenesis. ${ }^{18}$ As the reduced branching morphogenesis is also observed in the FSP-ER $\alpha$ KO mice, we were interested in determining whether BMP4 and other paracrine factors are regulated by prostate stromal $E R \alpha$ to influence branching morphogenesis. We examined the expression of several important genes involved in prostatic branching morphogenesis, including sonic hedgehog (Shh), the fibroblast growth factor (FGF) family, insulin-like growth factor-1 (IGF-1), and the bone morphogenesis protein $(B M P)$ family by RT Q-PCR. Our results showed that loss of stromal $\mathrm{ER} \alpha$ in the mouse prostate leads to reduced expression of IGF1 , and increased expression of BMP4 in the VP of FSP-ER $\alpha$ KO (Figure 6a, $* P<0.05$ ). There are no significant changes in the expression of Shh, FGF7, FGF10 or BMP7, known to inhibit branching morphogenesis in the prostate. ${ }^{42}$ In the pes-ER $\alpha \mathrm{KO}$, expression levels of these genes showed no significant difference. We also observed that expression of IGF-1 decreases and BMP4 increases in the DLP of
FSP-ER $\alpha$ KO (Figure 6b). Furthermore, FGF10 is reduced in DLPs of FSP-ER $\alpha \mathrm{KO}$ as compared to those of pes-ER $\alpha \mathrm{KO}$ and WT. However, we found IGF-1 and FGF7 expressions are slightly higher in the DLP of pes-ER $\alpha$ KO as compared to that of FSP-ER $\alpha$ KO. The slightly increased IGF-1 and FGF7 expressions may compensate for the BMP4 growth inhibition effects in the prostates of pes-ER $\alpha \mathrm{KO}$ mice. Together, our data suggested that there is a slightly different cytokine growth factor profile in the VP and DLP of ER $\alpha$ KO mice.

Collectively, the prostate branching morphogenesis can be regulated by inhibiting factors, such as BMP4, as well as promoting factors including IGF-1 and FGF10. The current studies demonstrate that loss of stromal fibroblast ER $\alpha$ could alter the expression of important stromal factors that are involved in prostatic branching morphogenesis, and our results also suggest that stromal fibroblast $\mathrm{ER} \alpha$ acts through a paracrine mechanism to regulate prostatic branching morphogenesis.

\section{DISCUSSION}

The prostate is a glandular structure consisting of epithelial and stromal compartments. A growing body of evidence has suggested that 
$a$

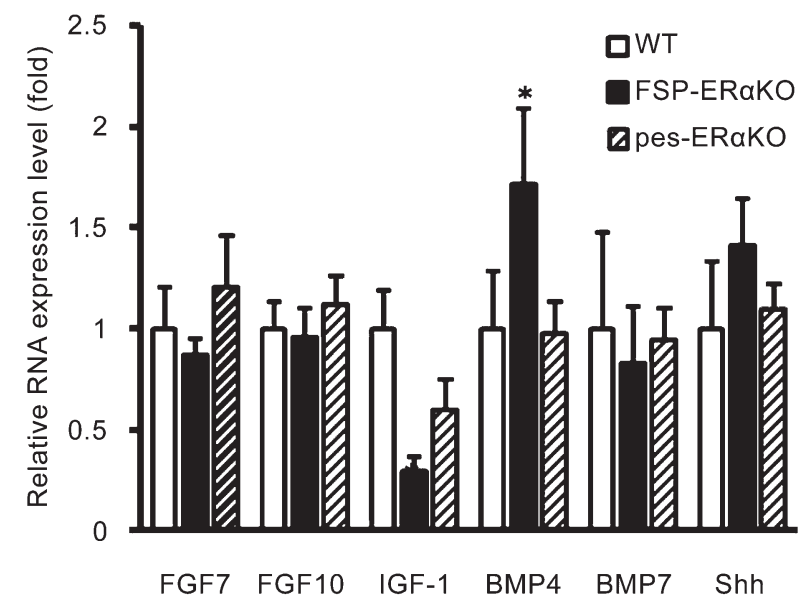

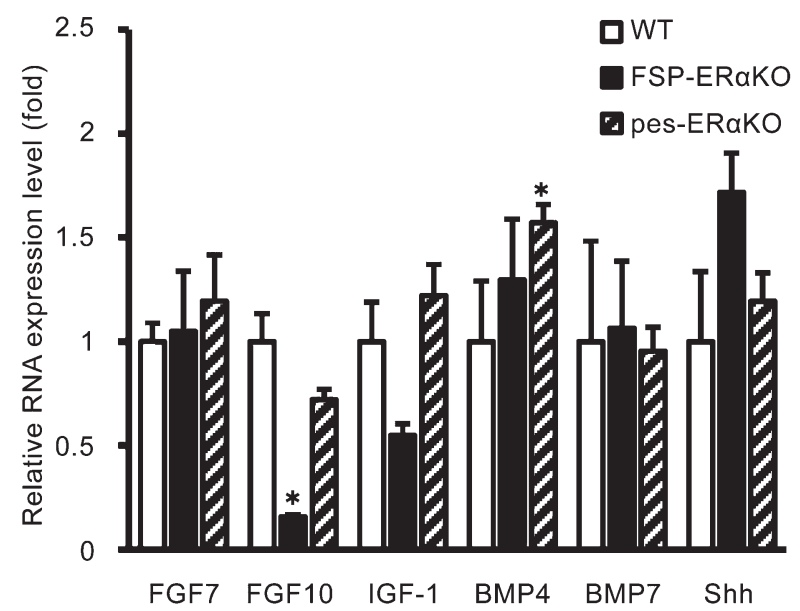

Figure 6 The genes regulated by stromal ER $\alpha$ in mouse prostate. Comparison of the expression levels of the genes involved in prostatic branching morphogenesis between FSP-ER $\alpha$ KO, pes-ER $\alpha$ KO and WT littermates by RT-PCR. Assays were performed on RNA from the VP (a) and DLP (b) of individual mouse and then averaged for the gene expression. ${ }^{*} P<0.05 \mathrm{vs}$. WT littermates ( $n=4$, statistically significant by unpaired $t$-test). $\beta$-actin was used as internal control. DLP, dorso-lateral prostate; ER, estrogen receptor; FSP, fibroblast-specific protein; IHC, immunohistochemistry; KO, knockout; pes-ER $\alpha$ KO, prostate epithelial cellspecific ER $\alpha$ KO; RT-PCR, real-time PCR; VP, ventral prostate; WT, wild type.

estrogen signaling exerts a direct impact on prostate pathogenesis and cancer. $^{18,21,43,44}$ Previous studies from conventional ER KO mice revealed that $\mathrm{ER} \alpha$, not $\mathrm{ER} \beta$, is the critical receptor to mediate the estrogens response in those processes. ${ }^{7,8,19,21}$ To investigate the in vivo roles of ER $\beta$ in mouse prostate development, the neo-ER $\beta$ KO mouse model was applied. The neo-ER $\beta$ KO male mice from Chapel Hill revealed a hyperplastic prostate, ${ }^{13}$ while the same transgenic mice housed at Karolinska Institute presented with prostatic intraepithelial neoplasia. ${ }^{35}$ However, those phenotypes were not generally observed in the similar neo-ER $\beta$ mice generated by other groups. ${ }^{45}$ Recently, a new and improved ER $\beta K O$ mouse model has been developed in which exon III of the ER $\beta$ gene was deleted by Cre-loxP mediated excision and was devoid of any transcript downstream of exon III. ${ }^{46}$ The studies using the Cre-loxP ER $\beta$ KO mouse model showed that ER $\beta$ is not required for the development and homeostasis of the major body systems including the prostate, which further confirmed the important role of $\mathrm{ER} \alpha$, not $\mathrm{ER} \beta$, in the estrogen-mediated response in the prostate.

FSP-Cre-mediated excision of ER $\alpha$ could occur in multiple reproductive organs prenatally including the testes and epididymides (Figure 1d). Therefore, we examined whether there is any abnormality of fertility in the FSP-ER $\alpha$ KO. Compared to ACTB-ER $\alpha$ KO males, FSP-ER $\alpha$ KO males are fertile with normal development of testes and epididymides and serum $\mathrm{T}$ levels, which suggested that a prenatal deletion of stromal fibroblast $\mathrm{ER} \alpha$ in the male reproductive organs does not affect male fertility. We also further delineated that loss of stromal fibroblast $\mathrm{ER} \alpha$ in the mouse prostate glands resulted in reduced branching morphogenesis in FSP-ER $\alpha$ KO mice. FSP-Cre cannot completely knock out $\mathrm{ER} \alpha$ in the stromal cells, and currently, there is no perfect stromal Cre mouse model available. However, FSP-Cre is known to knock down 50\%-65\% of floxed target genes in the mouse prostate, ${ }^{44}$ which has been widely used to knock out a variety of target genes. ${ }^{30,47}$ It is well documented that a low dose of estrogen can increase AR expression, prostate weight and prostatic budding in the rodent prostates, ${ }^{48,49}$ which suggested that the physiological range of estrogens via ERs might promote prostatic branching morphogenesis and is consistent with our current studies that either loss of ER $\alpha$ in whole body ${ }^{18}$ or only in stromal cells inhibit branching morphogenesis in the rodent prostates. It is well known that there are endogenous estrogens in males. Fat cells can produce estrogen, $\mathrm{T}$ can be converted to E2 and DHEA can be converted by $17 \beta$ DSH-1 to estrogenic compounds. ${ }^{50}$ Therefore, results comparing WT, pes$\mathrm{ER} \alpha \mathrm{KO}$ and FSP-ER $\alpha \mathrm{KO}$ male prostates have provided the in vivo evidence that stromal $\mathrm{ER} \alpha$ is important to regulate prostate branching morphogenesis. In addition, the high dose of estrogen will induce estrogen imprinting effect in neonatal prostate and SQM in the adult rodent prostates. We have recently published the characterization of the response of tissue-specific ER $\alpha \mathrm{KO}$ prostates to high doses of estrogen. ${ }^{44}$ From our studies, we found that in response to estrogen, FSP-ER $\alpha$ KO prostates develop a full and uniform SQM, In contrast, loss of epithelial ER $\alpha$ inhibits estrogen-mediated SQM evidenced by significantly decreased CK10 positive squamous cell stratification and differentiation, reduced upregulation of $\mathrm{ER} \alpha$ expression, and the presence of normal proliferative activities in the estrogen-treated pes$\mathrm{ER} \alpha \mathrm{KO}$ prostates. Together, these in vivo results suggest that stromal $\mathrm{ER} \alpha$ is responsible for prostate branching morphogenesis and epithelial $\mathrm{ER} \alpha$ is required for estrogen-mediated proliferative response and SQM development. Moreover, the branching morphogenesis observed between WT and FSP-ER $\alpha$ KO was significantly different. Our results indicated that phenotype changes are observed in VP and DLP, but not AP. The major reason may be that FSP-Cre was specifically expressed in the prostatic stromal fibroblast cells with strong expression in VP and DLP compared to AP (Figure 1b). Although the resulting phenotypes of arrested branching morphogenesis are similar to ACTB-ER $\alpha$ KO, the current study provides direct evidence that loss of $E R \alpha$ in the stromal fibroblast cells, but not in epithelial cells, of prostate reduces the formation of prostatic ductal tips and impairs branching morphogenesis. Moreover, in addition to BMP4 regulation of ER $\alpha$, we also found that IGF-1 can be regulated by $\mathrm{ER} \alpha$ in prostate fibroblast cells of intact mice in vivo and in primary cultured rUGM cells in vitro. Those stromal factors are specifically regulated by $\mathrm{ER} \alpha$, because genes in the same family, such as FGF7 and FGF10, or other stromal factors are not affected by loss of stromal fibroblast $\mathrm{ER} \alpha$ in the mouse prostate. IGF-1 has been considered as a growth factor and is well suited to act as a paracrine factor to 
modulate mesenchymal-epithelial interaction in the prostate. The important roles of IGF-1 in normal prostate is revealed by the recent report that grafted prostatic tissue from IGF-1 KO and IGF-1R KO mice have retarded prostatic growth relative to grafts of normal urogenital sinus. ${ }^{51}$ Our current studies emphasized IGF-1 could be involved in the prostatic development as a downstream gene regulated by stromal estrogen signaling in the prostate. Further studies are needed to determine the mechanism by which ER $\alpha$ regulates IGF-1 expression.

Our previous studies found that proliferation of prostate stromal cells was significantly reduced in ACTB-ER $\alpha$ KO mice at 1-week-old, which could partly contribute to the reduced branching in the ACTBER $\alpha$ KO prostates. ${ }^{18}$ Interestingly, we did not observe any significant changes of proliferation rate in prostate epithelial and stromal cells of FSP-ER $\alpha$ KO compared to WT mice at 1-week-old (Figure 3b). Instead, we observed that the apoptotic index of FSP-ER $\alpha$ KO prostates was significantly higher than WT prostates (Figure $3 \mathbf{c}$ and $\mathbf{d}$ ). The phenotypic difference in the prostates of ACTB-ER $\alpha$ KO and FSP$\mathrm{ER} \alpha \mathrm{KO}$ mice suggested that $\mathrm{ER} \alpha$ in stromal compartments may exert tissue or cell type-specific function and be involved in the prostatic stromal cell survival.

Probasin-Cre-mediated excision of $\mathrm{ER} \alpha$ is highly specific in the prostatic epithelial cells (Figure 5c). As expected, pes-ER $\alpha$ KO males develop with normal fertility due to restricted Cre expression in prostatic epithelial cells. In contrast to FSP-ER $\alpha$ KO mice, the pes-ER $\alpha \mathrm{KO}$ males develop normal prostates with normal ductal morphogenesis. The results suggest that postnatal deletion of epithelial ER $\alpha$ by probasin-Cre will not affect prostate homeostasis from fetal to adult stage. It has been well known that the mouse prostate undergoes extensive branching morphogenesis during the first 15 days of life. ${ }^{30}$ Probasin promoter-driven Cre excision is barely detectable in the prostate during the first 15 days of neonatal mice, ${ }^{37}$ which could be the reason that we did not observe the changes in the pes-ER $\alpha$ KO prostate development. In order to further define the role of epithelial ER $\alpha$ in the early prostatic development, the use of NKX3.1 Cre could be an ideal strategy, because its Cre activity begins to express at embryonic stage E17.5 in a prostatic epithelium-specific manner. ${ }^{52}$ Alternatively, we could utilize other epithelial specific Cre mice, CK18-Cre and CK14-Cre, ${ }^{53,54}$ to disrupt the $E R \alpha$ gene in the mouse prostate epithilium. In addition, Omoto et al. ${ }^{16}$ has shown that the expression of ER $\alpha$ is stage-dependent and its expression in the mouse prostate epithelial cells could be changed from negative to positive under different challenges, such as estrogenic compound exposure, ${ }^{44}$ castration followed by androgen supplementation ${ }^{16}$ and pathophysiological progression from normal prostate to benign prostatic hyperplasia or prostate cancer. Therefore, it might be necessary to combine cell type-specific and temporal control Cre activity to knock out $\mathrm{ER} \alpha$ in order to fully understand the roles of stromal $v s$. epithelial ER $\alpha$ in the prostate development, as well as prostate disease progression. ${ }^{55}$

In conclusion, we have generated prostate cell type-selective FSP$\mathrm{ER} \alpha \mathrm{KO}$ and pes-ER $\alpha \mathrm{KO}$ mouse models and have characterized the functions of $\mathrm{ER} \alpha$ in the male genital tract and prostates using those two ER $\alpha$ KO mouse models. Our data support the hypothesis that ER $\alpha$ regulates the prostate in the context of stromal and epithelial interaction. The current studies using these tissue-specific $\mathrm{KO}$ mice extended our previous ACTB-ER $\alpha$ KO findings by validating and confirming that stromal fibroblast $\mathrm{ER} \alpha$ plays an important role in prostate epithelial branching morphogenesis and prostatic homeostasis. Our study also demonstrated that there are several paracrine factors regulated by $\mathrm{E} 2 / \mathrm{ER} \alpha$, and IGF-1 and BMP4 are responsible for E2/ER $\alpha$ signals in the prostate stromal cells.

\section{AUTHOR CONTRIBUTIONS}

$\mathrm{MC}$ and CRY designed, conducted experiments and manuscript writing. CRS and JD were assistants in revision. HHL breeded mice. SY was involved in experimental design and manuscript writing.

\section{COMPETING FINANCIAL INTERESTS}

The authors have no financial or any other conflict of interest to declare regarding the contents of this article.

\section{ACKNOWLEDGMENTS}

This work was supported by National Cancer Institute grant CA137474 and Taiwan Department of Health Clinical Trial, Research Center of Excellence (DOH99-TD-B-111-004 to China Medical University, Taichung, Taiwan). We thank Drs H. L. Moses and N. A. Bhowmick for providing FSP-Cre transgenic mouse and Karen Wolf for manuscript preparation.

1 Chang CS, Kokontis J, Liao ST. Structural analysis of complementary DNA and amino acid sequences of human and rat androgen receptors. Proc Natl Acad Sci USA 1988; 85: 7211-5.

2 Cunha GR, Chung LW, Shannon JM, Taguchi O, Fujii H. Hormone-induced morphogenesis and growth: role of mesenchymal-epithelial interactions. Recent Prog Horm Res 1983; 39: 559-98.

3 Cunha GR, Hayward SW, Dahiya R, Foster BA. Smooth muscle-epithelial interactions in normal and neoplastic prostatic development. Acta Anat (Basel) 1996; 155: 63-72.

4 Mawhinney MG, Neubauer BL. Actions of estrogen in the male. Invest Urol 1979; 16: 409-20.

5 vom Saal FS, Timms BG, Montano MM, Palanza P, Thayer KA et al. Prostate enlargement in mice due to fetal exposure to low doses of estradiol or diethylstilbestrol and opposite effects at high doses. Proc Natl Acad Sci USA 1997; 94: 2056-61.

6 Timms BG, Petersen SL, vom Saal FS. Prostate gland growth during development is stimulated in both male and female rat fetuses by intrauterine proximity to female fetuses. J Urol 1999; 161: 1694-701.

7 Jarred RA, Cancilla B, Prins GS, Thayer KA, Cunha GR et al. Evidence that estrogens directly alter androgen-regulated prostate development. Endocrinology 2000; 141: 3471-7.

8 Prins GS. Neonatal estrogen exposure induces lobe-specific alterations in adult rat prostate androgen receptor expression. Endocrinology 1992; 130: 3703-14.

9 Rajfer J, Coffey DS. Sex steroid imprinting of the immature prostate. Long-term effects. Invest Urol 1978; 16: 186-90.

10 Taylor RA, Cowin P, Couse JF, Korach KS, Risbridger GP. 17beta-estradiol induces apoptosis in the developing rodent prostate independently of ERalpha or ERbeta. Endocrinology 2006; 147: 191-200.

11 Deroo BJ, Korach KS. Estrogen receptors and human disease. J Clin Invest 2006; 116: $561-70$

12 Paech K, Webb P, Kuiper GG, Nilsson S, Gustafsson J et al. Differential ligand activation of estrogen receptors ERalpha and ERbeta at AP1 sites. Science 1997; 277: $1508-10$

13 Krege JH, Hodgin JB, Couse JF, Enmark E, Warner M et al. Generation and reproductive phenotypes of mice lacking estrogen receptor beta. Proc Natl Acad Sci USA 1998; 95: 15677-82.

14 Akingbemi BT, Ge R, Rosenfeld CS, Newton LG, Hardy DO et al. Estrogen receptoralpha gene deficiency enhances androgen biosynthesis in the mouse Leydig cell. Endocrinology 2003; 144: 84-93.

15 Eddy EM, Washburn TF, Bunch DO, Goulding EH, Gladen BC et al. Targeted disruption of the estrogen receptor gene in male mice causes alteration of spermatogenesis and infertility. Endocrinology 1996; 137: 4796-805.

16 Omoto Y, Imamov O, Warner M, Gustafsson JA. Estrogen receptor al pha and imprinting of the neonatal mouse ventral prostate by estrogen. Proc Natl Acad Sci USA 2005; 102: 1484-9.

17 Chen M, Wolfe A, Wang X, Chang C, Yeh S et al. Generation and characterization of a complete null estrogen receptor alpha mouse using Cre/LoxP technology. Mol Cell Biochem 2009; 321: 145-53.

18 Chen M, Hsu I, Wolfe A, Radovick S, Huang K et al. Defects of prostate development and reproductive system in the estrogen receptor-al pha null male mice. Endocrinology 2009; 150: 251-9.

19 Prins GS, Birch L, Couse JF, Choi I, Katzenellenbogen B et al. Estrogen imprinting of the developing prostate gland is mediated through stromal estrogen receptor alpha: studies with alphaERKO and betaERKO mice. Cancer Res 2001; 61: 6089-97.

20 Prins GS, Birch L. Neonatal estrogen exposure up-regulates estrogen receptor expression in the developing and adult rat prostate lobes. Endocrinology 1997; 138: 1801-9.

21 Risbridger G, Wang H, Young P, Kurita T, Wang YZ et al. Evidence that epithelial and mesenchymal estrogen receptor-alpha mediates effects of estrogen on prostatic epithelium. Dev Biol 2001; 229: 432-42. 
22 Ricke WA, McPherson SJ, Bianco JJ, Cunha GR, Wang Y et al. Prostatic hormonal carcinogenesis is mediated by in situ estrogen production and estrogen receptor alpha signaling. FASEB J 2008; 22: 1512-20.

23 MaoX, Fujiwara Y, Orkin SH. Improved reporter strain for monitoring Cre recombinasemediated DNA excisions in mice. Proc Natl Acad Sci USA 1999; 96: 5037-42.

24 Soriano P. Generalized lacZ expression with the ROSA26 Cre reporter strain. Nat Genet 1999; 21:70-1.

25 Chen M, Ni J, Zhang Y, Muyan M, Yeh S. ERAP7 5 functions as a coactivator to enhance estrogen receptor alpha transactivation in prostate stromal cells. Prostate 2008; 68: 1273-82.

26 Iwano M, Fischer A, Okada H, Plieth D, Xue C et al. Conditional abatement of tissue fibrosis using nucleoside analogs to selectively corrupt DNA replication in transgenic fibroblasts. Mol Ther 2001; 3: 149-59.

27 I wano M, Plieth D, Danoff TM, Xue C, Okada H et al. Evidence that fibroblasts derive from epithelium during tissue fibrosis. J Clin Invest 2002; 110: 341-50.

28 Strutz F, Okada H, Lo CW, Danoff T, Carone RL et al. Identification and characterization of a fibroblast marker: FSP1. J Cell Biol 1995; 130: 393-405.

29 Bhowmick NA, Chytil A, Plieth D, Gorska AE, Dumont N et al. TGF-beta signaling in fibroblasts modulates the oncogenic potential of adjacent epithelia. Science 2004 303: 848-51.

30 Sugimura Y, Cunha GR, Donjacour AA. Morphogenesis of ductal networks in the mouse prostate. Biol Reprod 1986; 34: 961-71.

31 Niu Y, Altuwaijri S, Yeh S, Lai KP, Yu S et al. Targeting the stromal androgen receptor in primary prostate tumors at earlier stages. Proc Natl Acad Sci USA 2008; 105 12188-93.

32 Niu Y, Altuwaijri S, Lai KP, Wu CT, Ricke WA et al. Androgen receptor is a tumor suppressor and proliferator in prostate cancer. Proc Natl Acad Sci USA 2008; 105: 12182-7.

33 Yu S, Yeh CR, Niu Y, Chang HC, Tsai YC et al. Altered prostate epithelial development in mice lacking the androgen receptor in stromal fibroblasts. Prostate $2011 ; 72$ : 437-49.

34 Yu S, Zhang C, Lin CC, Niu Y, Lai KP et al. Altered prostate epithelial development and IGF-1 signal in mice lacking the androgen receptor in stromal smooth muscle cells. Prostate $2011 ; 71: 517-24$.

35 Weihua Z, Makela S, Andersson LC, Salmi S, Saji S et al. A role for estrogen receptor beta in the regulation of growth of the ventral prostate. Proc Natl Acad Sci USA 2001; 98: 6330-5.

36 McPherson SJ, Ellem SJ, Simpson ER, Patchev V, Fritzemeier KH et al Essential role for estrogen receptor beta in stromal-epithelial regulation of prostatic hyperplasia. Endocrinology 2007; 148: 566-74.

37 Wu X, Wu J, Huang J, Powell WC, Zhang J et al. Generation of a prostate epithelial cellspecific Cre transgenic mouse model for tissue-specific gene ablation. Mech Dev 2001; 101: 61-9.

38 Wu CT, Altuwaijri S, Ricke WA, Huang SP, Yeh S et al. Increased prostate cell proliferation and loss of cell differentiation in mice lacking prostate epithelial androgen receptor. Proc Natl Acad Sci USA 2007; 104: 12679-84.
39 Wang S, Garcia AJ, Wu M, Lawson DA, Witte ON et al. Pten deletion leads to the expansion of a prostatic stem/progenitor cell subpopulation and tumor initiation. Proc Natl Acad Sci USA 2006; 103: 1480-5

40 Marker PC, Donjacour AA, Dahiya R, Cunha GR. Hormonal, cellular, and molecular control of prostatic development. Dev Biol 2003; 253: 165-74.

41 Lamm ML, Podlasek CA, Barnett DH, Lee J, Clemens JQ et al. Mesenchymal facto bone morphogenetic protein 4 restricts ductal budding and branching morphogenesis in the developing prostate. Dev Biol 2001; 232: 301-14.

42 Grishina IB, Kim SY, Ferrara C, Makarenkova HP, Walden PD. BMP7 inhibits branching morphogenesis in the prostate gland and interferes with Notch signaling. Dev Biol 2005; 288: 334-47.

43 King KJ, Nicholson HD, Assinder SJ. Effect of increasing ratio of estrogen: androgen on proliferation of normal human prostate stromal and epithelial cells, and the malignant cell line LNCaP. Prostate 2006; 66: 105-14.

44 Chen M, Yeh CR, Chang HC, Vitkus S, Wen XQ et al. Loss of epithelial oestrogen receptor $\alpha$ inhibits oestrogen-stimulated prostate proliferation and squamous metaplasia via in vivo tissue selective knockout models. J Pathol 2012; 226: 17-27.

45 Dupont S, Krust A, Gansmuller A, Dierich A, Chambon P et al. Effect of single and compound knockouts of estrogen receptors alpha (ERalpha) and beta (ERbeta) on mouse reproductive phenotypes. Development 2000; 127: 4277-91.

46 Antal MC, Krust A, Chambon P, Mark M. Sterility and absence of histopathological defects in nonreproductive organs of a mouse ERbeta-null mutant. Proc Nat/ Acad Sci USA 2008; 105: 2433-8.

47 Trimboli AJ, Cantemir-Stone CZ, Li F, Wallace JA, Merchant A et al. Pten in stroma fibroblasts suppresses mammary epithelial tumours. Nature 2009; 461: 1084-91.

48 Timms BG, Petersen SL, vom Saal FS. Prostate gland growth during development is stimulated in both male and female rat fetuses by intrauterine proximity to female fetuses. J Urol 1999; 161: 1694-701

49 vom Saal FS, Timms BG, Montano MM, Palanza P, Thayer KA et al. Prostate enlargement in mice due to fetal exposure to low doses of estradiol or diethylstilbestrol and opposite effects at high doses. Proc Natl Acad Sci USA 1997; 94: 2056-61.

50 Labrie F. Future perspectives of selective estrogen receptor modulators used alone and in combination with DHEA. Endocr Relat Cancer 2006; 13: 335-55.

51 Hayward SW, Cunha GR. The prostate: development and physiology. Radiol Clin North Am 2000; 38: 1-14.

52 Thomsen MK, Butler CM, Shen MM, Swain A. Sox9 is required for prostate development. Dev Biol 2008; 316: 302-11.

53 Wen F, Cecena G, Munoz-Ritchie V, Fuchs E, Chambon P et al. Expression of conditional cre recombinase in epithelial tissues of transgenic mice. Genesis 2003; 35: 100-6.

54 Jonkers J, Meuwissen R, van der Gulden $\mathrm{H}$, Peterse $\mathrm{H}$, van der Valk $\mathrm{M}$ et al. Synergistic tumor suppressor activity of BRCA2 and p53 in a conditional mouse model for breast cancer. Nat Genet 00129: 418-25.

55 Wolfe A, Divall S, Singh SP, Nikrodhanond AA, Baria AT et al. Temporal and spatial regulation of $\mathrm{CRE}$ recombinase expression in gonadotrophin-releasing hormone neurones in the mouse. J Neuroendocrinol 2008; 20: 909-16. 